\title{
Conchixes: organic scaffolds which resemble the size and shapes of mollusks shells, their isolation and potential multifunctional applications
}

\author{
Hermann Ehrlich ${ }^{1,2} \cdot$ Rajko Martinović $^{3}$. Danijela Joksimović ${ }^{3} \cdot$ laroslav Petrenko ${ }^{1}$ Stefano Schiaparelli ${ }^{4,5}$. \\ Marcin Wysokowski ${ }^{1,6} \cdot$ Dmitry Tsurkan $^{7}$. Allison L. Stelling ${ }^{8} \cdot$ Armin Springer $^{9,10}$ - Michael Gelinsky ${ }^{9}$. \\ Aleksandar Joksimović ${ }^{3}$
}

Received: 25 May 2020 / Accepted: 14 June 2020

(c) The Author(s) 2020

\begin{abstract}
Molluscan shells are an example of a mineral-based biocomposite material, and most studies to date have focused on understanding their biomineralization mechanisms. Meanwhile, large amounts of these shells are produced as waste globally by seafood which is used by other industries as a source of biogenic calcium carbonates. In this study, we propose a simple methodological approach for isolation of Conchixes, the organic scaffolds that resemble the size and shapes of mollusks shells, using gentle EDTA-based demineralization of the shells. Such mineral-free biological materials have been extracted from selected representatives of marine and fresh water bivalves, as well as from marine and terrestrial gastropods under study. Key pathways to practical applications of molluscan conchixes with regards to pharmacy, cosmetics, feed and feed additives, biomedicine and bioinspired materials science are also discussed.
\end{abstract}

Keywords Biological materials $\cdot$ Conchiolin $\cdot$ Periostracum $\cdot$ Organic scaffolds $\cdot$ Mollusks $\cdot$ Shell, Bivalvia $\cdot$ Gastropoda $\cdot$ Biomineralization $\cdot$ Biomimetics

\section{Introduction}

Diverse representatives of the phylum Mollusca possess the ability to produce mineralized shells, whose main aim is to provide a protective armor [1]. Molluscan shells are the objects of intensive scientific investigations, mostly as model

Hermann Ehrlich

hermann.ehrlich@esm.tu-freiberg.de

1 Institute of Electronics and Sensor Materials, TU Bergakademie Freiberg, 09599 Freiberg, Germany

2 Center for Advanced Technology, Adam Mickiewicz University, 61614 Poznan, Poland

3 Institute of Marine Biology, University of Montenegro, 85330 Kotor, Montenegro

4 University of Genoa, Corso Europa 26, 16132 Genoa, Italy

5 Italian National Antarctic Museum (MNA, Section of Genoa), University of Genoa, Genoa, Italy

6 Faculty of Chemical Technology, Institute of Chemical Technology and Engineering, Poznan University of Technology, 60965 Poznan, Poland structures for understanding biomineralization principles [2-6], as indicators of environmental changes with respect to climate [7, 8], or chemical contaminations $[9,10]$. Special attention has been given to shells' biomechanical [11-16], biomimetic, and materials science properties [17-24].

7 TissueGUARD GmbH, 01217 Dresden, Germany

8 Department of Biochemistry, Duke University Medical Center, Durham, NC, USA

9 Centre for Translational Bone, Joint and Soft Tissue Research, Faculty of Medicine and University Hospital Carl Gustav Carus of Technische Universität Dresden, Fetscherstraße 74, 01307 Dresden, Germany

10 Medizinische Biologie und Elektronenmikroskopisches Zentrum (EMZ), Universitätsmedizin Rostock, 18055 Rostock, Germany 
However, parallel to pure scientific interest on molluscan shells, one direction that has raised much recent interest deals with shells as biological waste $[25,26]$. Both aquaculture and the seafood industry are amazing sources of edible marine and freshwater mollusks and, consequently, of millions of tons of shells as waste material. According to Morris and co-workers [27], "shells from the aquaculture industry are widely regarded as a nuisance waste product, yet at the same time, calcium carbonate is mined in the form of limestone and viewed as a valuable commodity". A similar situation can be suggested to exist with shells of edible terrestrial species, e.g. Helix pomatia (Linnaeus, 1758) and Cornu aspersum (Müller, 1774) [28], whose heliciculture has grown explosively $[29,30]$. Shells with more than $95 \%$ calcium carbonate used on a commercial scale are a viable alternative to mineral raw materials and have been mostly used as a biological source of calcium for poultry and other agricultural applications [27]. Other uses of this biocomposite include its potential as a building material [31, 32]. For example, the shells of Pacific oyster, Magallana gigas (Thunberg, 1793) (formerly known as Crassostrea gigas), which was the source of 3.08 million tons of shell waste only in 2003 [33], have been successfully used as the main component of artificial stones. The developed composite material consists of oyster shells incorporated in a synthetic polymeric resin [34]. Thus, the main strategies used at present for the disposal of shells is their transformation into powder or small particles as additives in building materials [35, 36], or high-temperature processing to obtain hydroxyapatite, or calcite for biomedical applications [36-42]. The utilization of molluscan shell waste as Ca-rich resource has been used also for the production of calcium oxide, which can be effectively applied in heterogeneous-based catalysts [43]. To obtain more detailed knowledge about the modern trends in application of moluscan shell waste, we recommend the recently published review by Jovic and co-workers [44].

Undoubtedly, shells are a mass product of shellfish processing and are a global source of calcium carbonates. Can the same be said for the organic phase in their composition? It is well recognized that such biomacromolecules as chitin [20, 42, 45-50], glycopolysaccharides [51-53] structural proteins $[42,54-56]$ and low molecular weight acidic proteins $[5,57-59]$ as well as lipids $[53,60,61]$ and pigments [62-66] are species dependent and have been found in different quantitative proportions within molluscs' shells [36]. It can be assumed with high probability that the organic matrix inside the shell turns out to be firmly walled up [67] and can survive for millions of years $[68,69]$. Confirmation of this can be found in the famous article by Steve Weiner entitled "Fossil mollusk shell organic matrix components preserved for 80 million years" [70].

In contrast to the traditionally used strategy for isolation of organic matter from powdered molluscan shells [35], we offer a methodological strategy for the allocation of organic matrices from natural (i.e. as collected) shells by demineralizing them in non-aggressive reagents. Gentle demineralization [71,72] allows us to isolate complete or partially demineralized shell on request (see Fig. 1).

For the first time, we present here the results of partial and complete demineralization of shells from different species of aquatic and land mollusks and outline the possible applications of the extracted organic matrices. All of them possess one characteristic feature: they completely repeat not only the contours of the shell but also its size, differing, however, in some species in the color of the organic phase. We propose to the definition of a new term, "conchix", based on "concha" that means "shell" and "matrix" where we mean the organic matrix.

\section{Materials and methods}

\subsection{Supply and keeping of mollusks shells}

Shell specimens of the terrestrial snail Cepaea nemoralis (Linnaeus, 1758) (Gastropoda) and Corbicula flumenia
Fig. 1 Schematic view on the principal of selective demineralization of mollusc shell by it partial immersion in a demineralizing reagent with the aim to obtain specimens with well distinguished mineral-organic matrix interphase

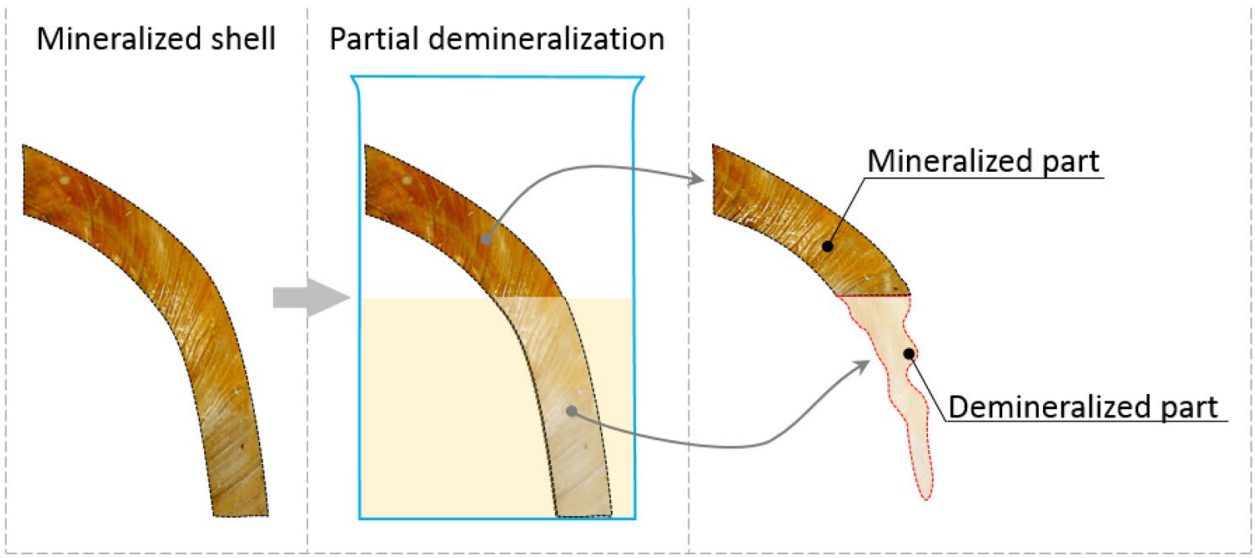


(Müller, 1774) (Bivalvia) have been collected on the banks of the Elbe River in Dresden (Germany). Shell samples of marine bivalves Haliotis tuberculata (Linnaeus, 1758) and Laternula elliptica (King, 1832) have been collected by Prof. A. Ereskovsky in Marseille (France), and by Dr. H. Poigner at King George Island (Antarctic Peninsula), respectively. Prior to demineralization, all of the specimens listed above have been cleaned in water ultrasonic bath during $30 \mathrm{~min}$, rinsed in dist. $\mathrm{H}_{2} \mathrm{O}$ and dried on air.

Shell samples of the Mediterranean mussel Mytilus galloprovincialis (Lamarck, 1819) were obtained from the local mussel farm at Sv. Nedjelja $\left(42^{\circ} 27^{\prime} 28.26^{\prime \prime} \mathrm{N}\right.$ $18^{\circ} 40^{\prime} 24.06^{\prime \prime} \mathrm{E}$ ), while empty shells of the fan mussel Pinna nobilis (Linnaeus, 1758) were found at the site Dobrota $\left(42^{\circ} 26^{\prime} 13.20^{\prime \prime} \mathrm{N} 18^{\circ} 45^{\prime} 44.82^{\prime \prime} \mathrm{E}\right)$ within the Boka Kotorska Bay, Adriatic Sea, Montenegro. Fouling organisms on shell surface and ligament were removed from each shell; afterwards the shells were washed with tap water and dried in the air.

\subsection{Isolation of Conchixes}

Decalcification of such shell samples as that of C. nemoralis, C. fluminea, H. tuberculate and L. elliptica was carried out using $7.4 \mathrm{pH}$ Osteosoft TM (Merck) solution (EDTA content $174.0 \mathrm{~g} / \mathrm{L}$ ) at $37^{\circ} \mathrm{C}$ up to complete dissolution of calcium carbonates. Isolated conchixes have been rinsed with $\mathrm{dH}_{2} \mathrm{O}$ and dried in the air on request.

Conchixes from M. galloprovincialis and P. nobilis shells were isolated by EDTA disodium salt dehydrate (VWR International bvba, Belgium) based solution. For the preparation of the solution, EDTA powder $(174 \mathrm{~g} / \mathrm{L})$ was gradually added in distilled water $\left(\mathrm{dH}_{2} \mathrm{O}\right)$, with permanent and vigorous stirring on a magnetic stirrer at room temperature. Since EDTA requires $\mathrm{pH} \geq 8$ to dissolve, $\mathrm{pH}$ value of solution was increased from 4,6 to 8 by gradual addition of sodium hydroxide pellets (CENTROHEM, Serbia). After complete dissolution of EDTA, $\mathrm{pH}$ was lowered to 7.25 by gradual addition of diluted hydrochloric acid (Neratovice, Czech Republic).

For the isolation of conchixes, we used one shell valve, while another one was kept for the later size and shape comparison between mineralized and demineralized shells. Shell valves used for isolation of conchixes were placed in a glass with previously prepared EDTA based solution and stored in laboratory incubator at $39{ }^{\circ} \mathrm{C}$ degrees. On every $24 \mathrm{~h}$, shells were rinsed with $\mathrm{dH}_{2} \mathrm{O}$ and solution was replaced. Duration of isolation process was $120 \mathrm{~h}$ (5 days) for M. galloprovincialis, while $P$. nobilis shells required $168 \mathrm{~h}$ (7 days). Obtained conchixes were thoroughly rinsed with $\mathrm{dH}_{2} \mathrm{O}$ and dried in the air on request.

\subsection{Digital, light and fluorescence microscopy}

The samples were observed and analyzed with the use of an advanced imaging and measurement system consisting of a Keyence VHX-6000 digital optical microscope and VHZ20R swing-head zoom lenses (magnification up to $200 \times$ ).

\subsection{SDS-PAGE}

After the gentle decalcification of purified Corbicula $\mathrm{flu}$ minea shells, the isolated conchixes were subjected to dialysis against deionized water using ROTH membranes (Germany) applied for dialysis of proteins with molecular weight exceeding $14 \mathrm{kDa}$. The dialysis was performed for $48 \mathrm{~h}$ at $4{ }^{\circ} \mathrm{C}$. The dialysed materials were dried under vacuum with a CHRIST lyophilizer (Germany) and stored at $4{ }^{\circ} \mathrm{C}$. For SDS gel analyses $100 \mathrm{mg}$ dried conchixes was crushed using an agate stone mortar. The powdered material was dissolved in a standard buffer ( $1 \mathrm{M}$ tris- $\mathrm{HCl}, \mathrm{pH} 6.8 ; 2.5 \%$ SDS, $10 \%$ glycerol, $0.0125 \%$ bromphenol blue); incubated for $5 \mathrm{~min}$ at $95{ }^{\circ} \mathrm{C}$; and then separated in 10 or $12 \%$ SDS polyacrylamide gel. Electrophoresis was performed for $1.5 \mathrm{~h}$ at $75 \mathrm{~V}$. To distinguish proteins, the obtained gel was stained with Coomassie Brilliant Blue R250 from the Gel Code Silver SNAP Stain Kit II (PIERCE, United States). As protein standards with the known molecular weight, we used a "Silver stain SDS molecular weight standard mixtures" set (Sigma, USA).

\subsection{Scanning electron microscopy (SEM)}

In case of SEM analysis samples were fixed with $2.5 \%$ glutaraldehyde in PBS at room temperature, washed with Naphosphate buffer $(0.1 \mathrm{M})$ dehydrated in an ascending series of acetone and critical point dried (Bal-Tec CPD 030). Samples were mounted on aluminum SEM-carrier with adhesive conductive carbon tape (Co. PLANO, Wetzlar) and coated with gold under vacuum using a Cressington 108 Auto sputter coater. The microstructure was determined using the Hitachi S4700 and XL 30 ESEM (Fa. Philips Electron Optics $\mathrm{GmbH}$ ) scanning electron microscopes.

\subsection{Transmission electron microscopy (TEM)}

For TEM (Transmission electron microscopy) investigations samples were fixed with $2.5 \%$ glutaraldehyde in PBS at room temperature, post fixed with $1.5 \%$ osmiumtetroxide, dehydrated in a graduated series of acetone (including a staining step with $1 \%$ uranylacetate) and embedded in Epoxy resin. Ultra-thin sections (about $70 \mathrm{~nm}$ ) of samples were prepared on a Leica EM UC6 ultramicrotome equipped with a Diatome diamond knife, mounted on pioloform coated copper grids, post stained with uranylacetate and Lead citrate (according to Reynolds, 1963) and analyzed in a Zeiss 
CTEM 902 at $80 \mathrm{kV}$ (University of Bayreuth). The microstructure was determined using the Hitachi S4700 and XL 30 ESEM (Fa. Philips Electron Optics GmbH) scanning electron microscopes. Samples were dried and covered with $\mathrm{Au}$ using a Cressington 108 Auto sputter coater.

\section{Results and discussion}

It is well recognized that quick demineralization of molluscan shells can be achieved using organic (i.e. acetic) or inorganic (i.e. hydrochloric) acids [71, 72]. However, the main drawback of this approach to demineralization is justified by the rapid release of carbon dioxide bubbles, which often leads to foaming and mechanical rupture of the brittle organic matrix into fragments. To overcome this challenge, we used gentler EDTA-based decalcification using Osteosoft ${ }^{\circledR}$ reagent, or self-prepared EDTA-based solutions with $\mathrm{pH}$ 7.25. Previously, good results with respect to the isolation of organic matrices from corals [73, 74], mollusks shells [20], sea urchin spines [75] using chelating EDTAcontaining solutions were reported. The effectiveness of this strategy was also confirmed in the present work, where it was possible to isolate conchixes of almost perfect integrity from representatives of both aquatic and terrestrial species of mollusks from different taxa (see Figs. 2, 3, 6, 7, 8, 9, and 11).
Let us consider some examples in more detail. In Fig. 2, the shell of the fan mussel Pinna nobilis (Linnaeus, 1758) that belongs to the largest (with up to $120 \mathrm{~cm}$ in total shell length) endemic bivalve of the Mediterranean Sea (see for details [76]) is represented before and after demineralization with EDTA solution. Demineralization process of $P$. nobilis was faster at the onset of the experiment due to the low thickness of the examined shell, that was observed by the lost of hardness in upper toward the widest part of the shell. In the first 2-3 days, more than $80 \%$ of shell become soft, however, 7 days (168 h) was needed to complete the isolation of conchix due to slower demineralization rate of the lower sized solid particle, placed in the area of the posterior adductor muscle. It was possible to isolate a corresponding conchix from its shell that partially preserved its integrity and brownish pigmentation in full. This biomaterial was elastic enough to be bent in half without the formation of visible macrodefects (Fig. 2b). Isolation of conchix from this endangered species can be crucial for bioanalytical studies on its chemistry and biochemistry, especially due to recognition of $P$. nobilis as being a reliable bioindicator for benthic coastal ecosystems according to the EU Marine Strategy Framework Directive (MSFD 2008/56/EC) [76]. There is little information concerning the nature and origin of conchix from this species. Previously, it was reported only that the water-soluble fraction of the prismatic layer isolated from $P$. nobilis contains glycoproteins and acidic sulfated sugars [55].
Fig. 2 Gentle demineralization of large shells of Pinna nobilis (Bivalvia) in EDTA-based solution $(174 \mathrm{~g} / \mathrm{L} ; \mathrm{pH} 7.25)$ during $168 \mathrm{~h}$ at $39^{\circ} \mathrm{C}$ leads to isolation of conchixes with practically similar size and shape (a). Isolated conchix is partially fragile, but elastic enough even to be folded (b) without it visible tearing

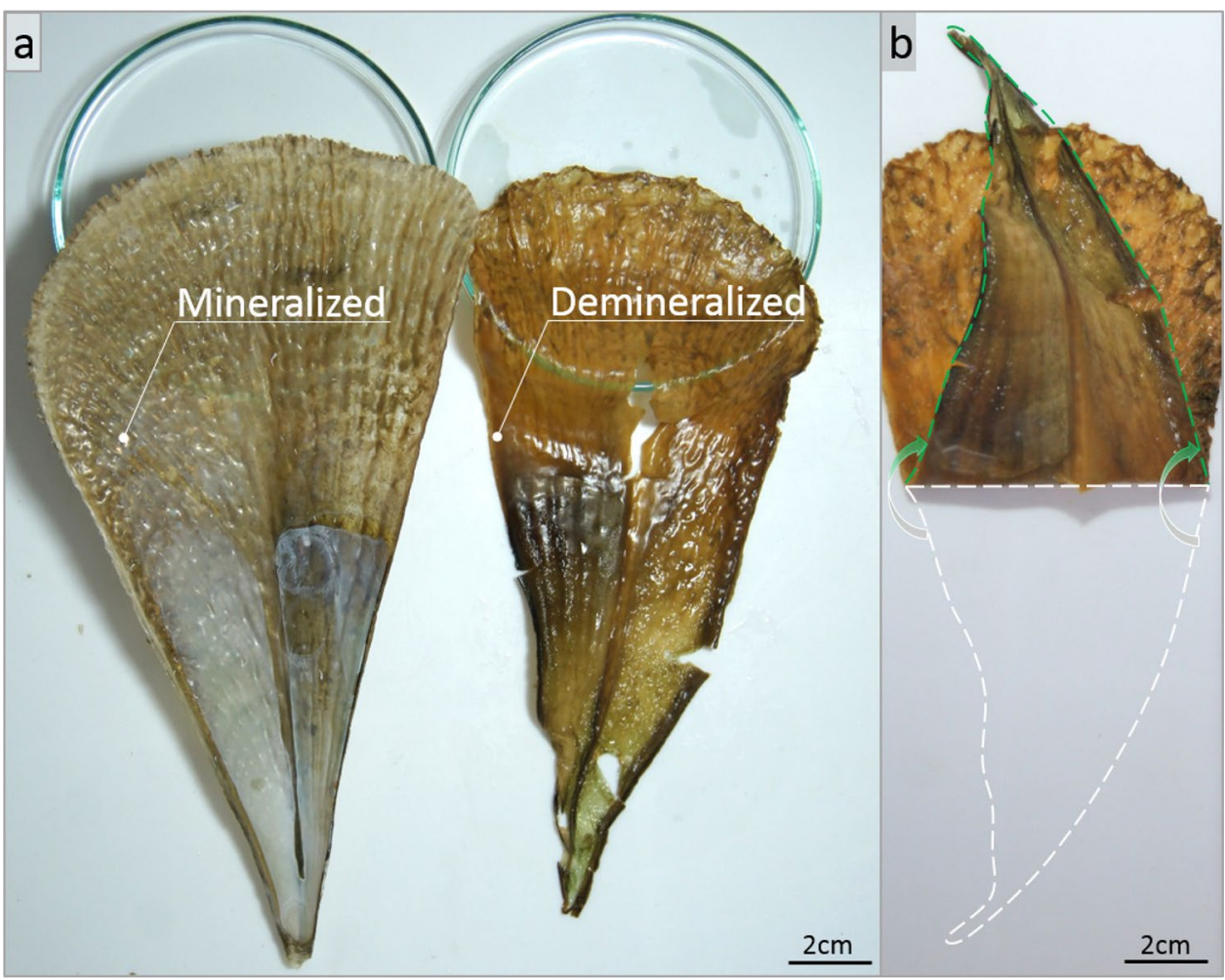




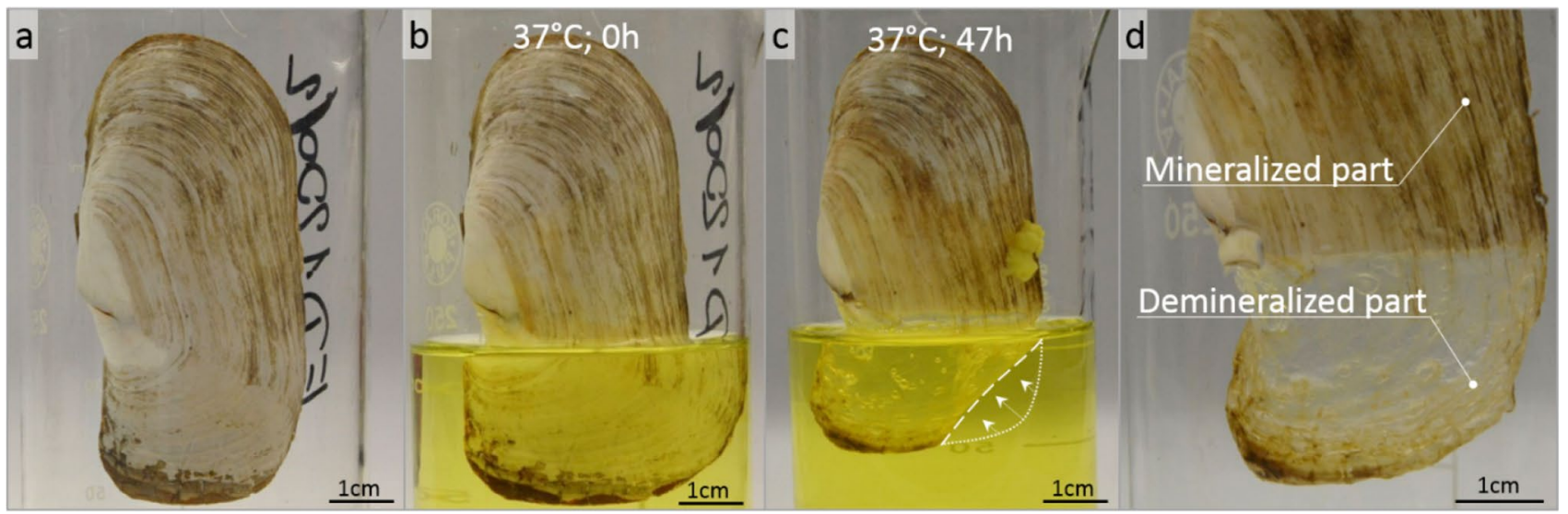

Fig. 3 Step by step imagery of selective demineralization of the L. elliptica shell using Osteosoft solution

Another object we choose for the study is Antarctic softshelled bivalve Laternula elliptica (King, 1832). This psychrophilic clam is a classical model organism which is used in a broad range of studies concerning metals accumulation [77-80], ocean acidification [81, 82], climate change [83-87] and molecular mechanisms of biomineralization [88]. In our experiments on demineralization with selected shells of L. elliptica using Osteosoft reagent, it was possible to carry out controlled partial demineralization (Figs. 3 and 4). It is well visible that conchix of selectively demineralized L. elliptica shell remains so firmly rooted in the mineralized shell that it does not fall off when mechanical stress is exerted (Fig. 4). Furthermore, we were able to cut demineralized, organic part of L. elliptica shell on request (Fig. 5) and use it for further analytical investigations.

As the main principles of molluscan shell organization [89] with respect to both water-soluble [90] and water-insoluble [91] organic phases are well known, we carried out experiments with special protein staining to show the localization of proteins within the conchix of L. elliptica (Fig. 6).
The obtained results show not homogenous distribution of the Coomassie blue stain on the surface of conchix from L. elliptica. This implies the presence of other organic components in the matrix besides proteins. We strongly believe that simple way to isolate conchixes from this intensively studied bivalve species will open a key way to obtain more detailed information of the role of organic phase in accumulation and possible storage of diverse contaminants (i.e. metals, pesticides) and naturally demineralization-remineralization mechanisms, which occurs under psychrophilic conditions and acidification of the oceans. We do not exclude that such conchixes can be used as a unique climate archive.

Also the next object of our study, the bivalve, M. galloprovincialis (Lamarck, 1819) remains to be an important indicator for the environmental control [92-94] of diverse trace elements [95, 96] and radionuclides [97]. However, in contrast to L. elliptica, this mollusc species is widely exploited as seafood and in some areas is also a broadly cultivated organism in aquaculture [98-101]. The shells of

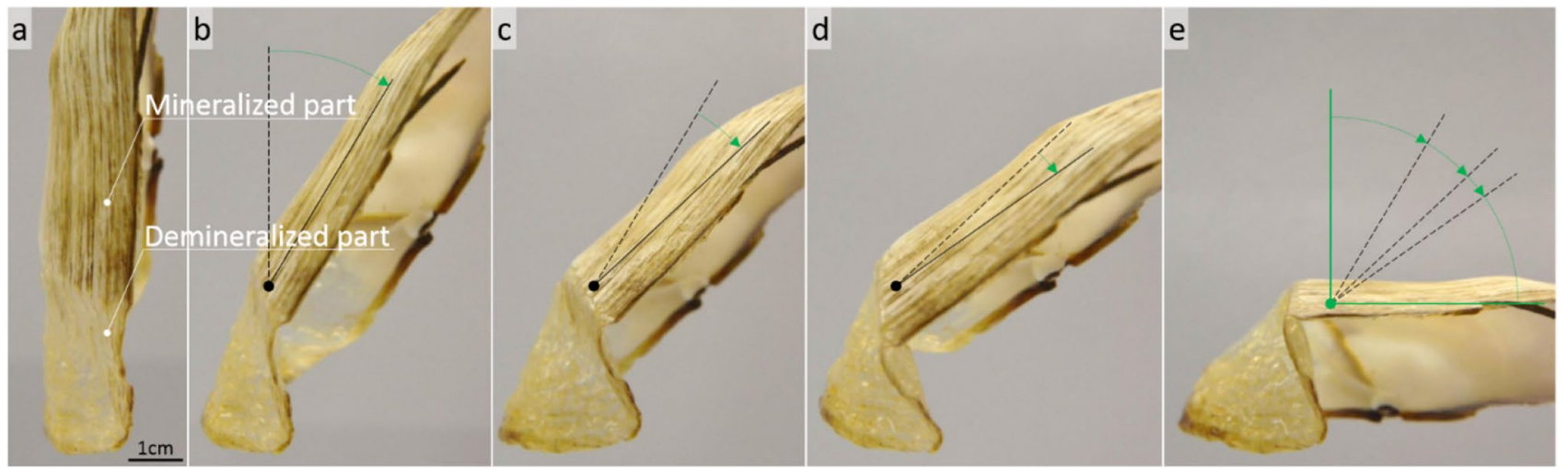

Fig. 4 Organic part of selectively demineralized L. elliptica shell (a) remains so firmly rooted in the shell that it does not fall off when mechanical stress is exerted $(\mathbf{b}-\mathbf{e})$ 

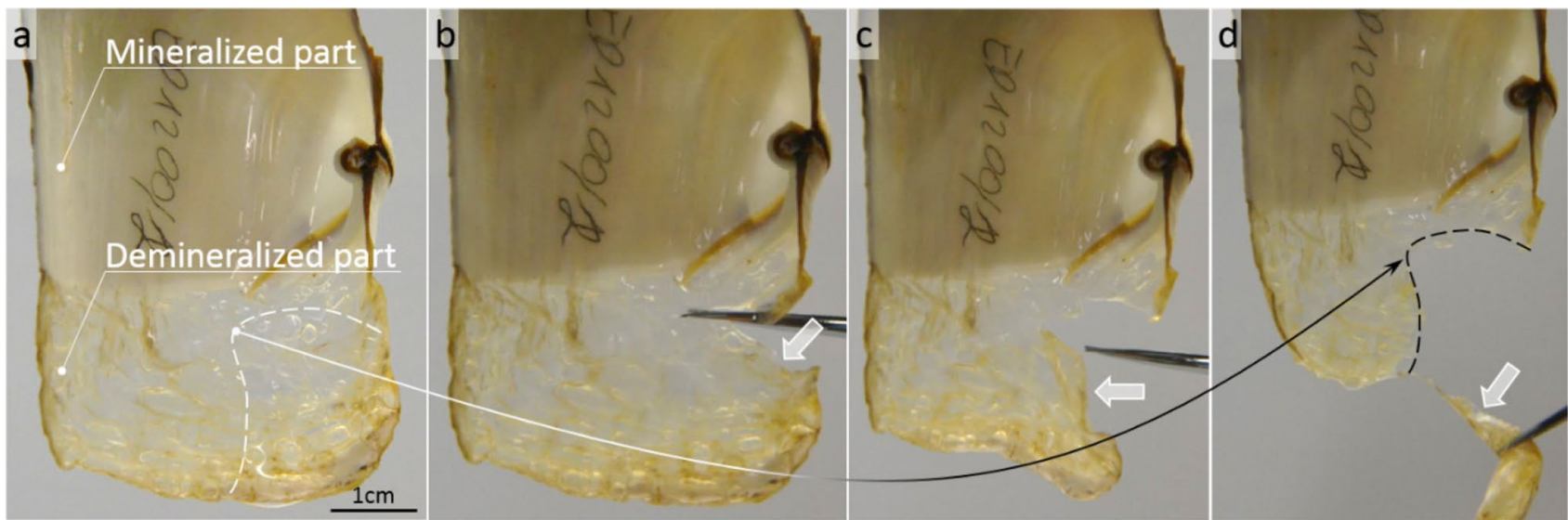

Fig. 5 Demineralized part of L. elliptica shell (a) can be cut out on request (b-d) and used for further studies

Fig. 6 Staining of partially demineralized L. elliptica shell (a) with Coomassie blue protein dye (b) confirms the presence of proteins within the organic matrix (c, arrows)

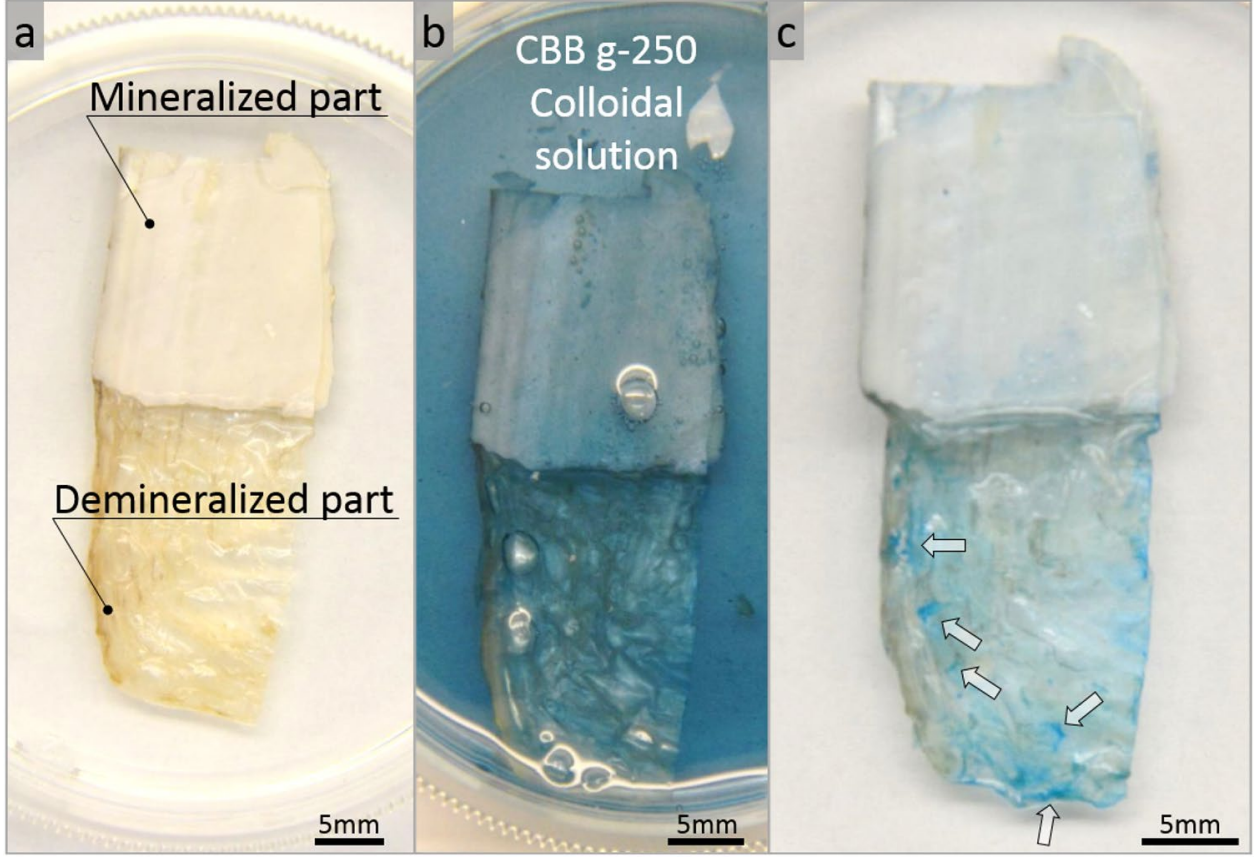

M. galloprovincialis have been already used for the trace element fingerprinting [102].

Here, we show the isolation of conchix also from this mussel (Fig. 7). Since the colour of M. galloprovincialis shell is black, it represents a suitable model for visualization of complete isolation process showing high contrast under the light. After $24 \mathrm{~h}$, part of the shell became orange-brown colored what was the additional indicator of demineralization (Fig. 7b). The shell was held with pincers showing that it was still in solid state. More than $50 \%$ of the shell was demineralised after $48 \mathrm{~h}$ (Fig. 7c) and became flexible. Thus, the shell was placed on a transparent glass surface for further monitoring of the conchix isolation. After $72 \mathrm{~h}$, demineralization was almost over (Fig. 7d). Complete demineralization occurred after $96 \mathrm{~h}$ (Fig. 7e) and conchix flexibility was confirmed after $120 \mathrm{~h}$ (Fig. 7). Isolated conchix was dried in the air which turned it into solid state (Fig. $7 \mathrm{~g}$ ), after $10 \mathrm{~min}$. immersion in $\mathrm{dH}_{2} \mathrm{O}$ (Fig. 7h), conchix became to be flexible again (Fig. 7i).

Due to recognition of $M$. galloprovincialis and related species as crucial players in the global production of marine food [103, 104], we believe that development of large-scale methods for isolation of conchixes from the million metric tons of their shells as biological waste materials should be a trend in the near future.

Marine gastropods belonging to Haliotidae family (also known as abalones) also possess large potential in the seafood industry and nacre jewellery, consequently are the 

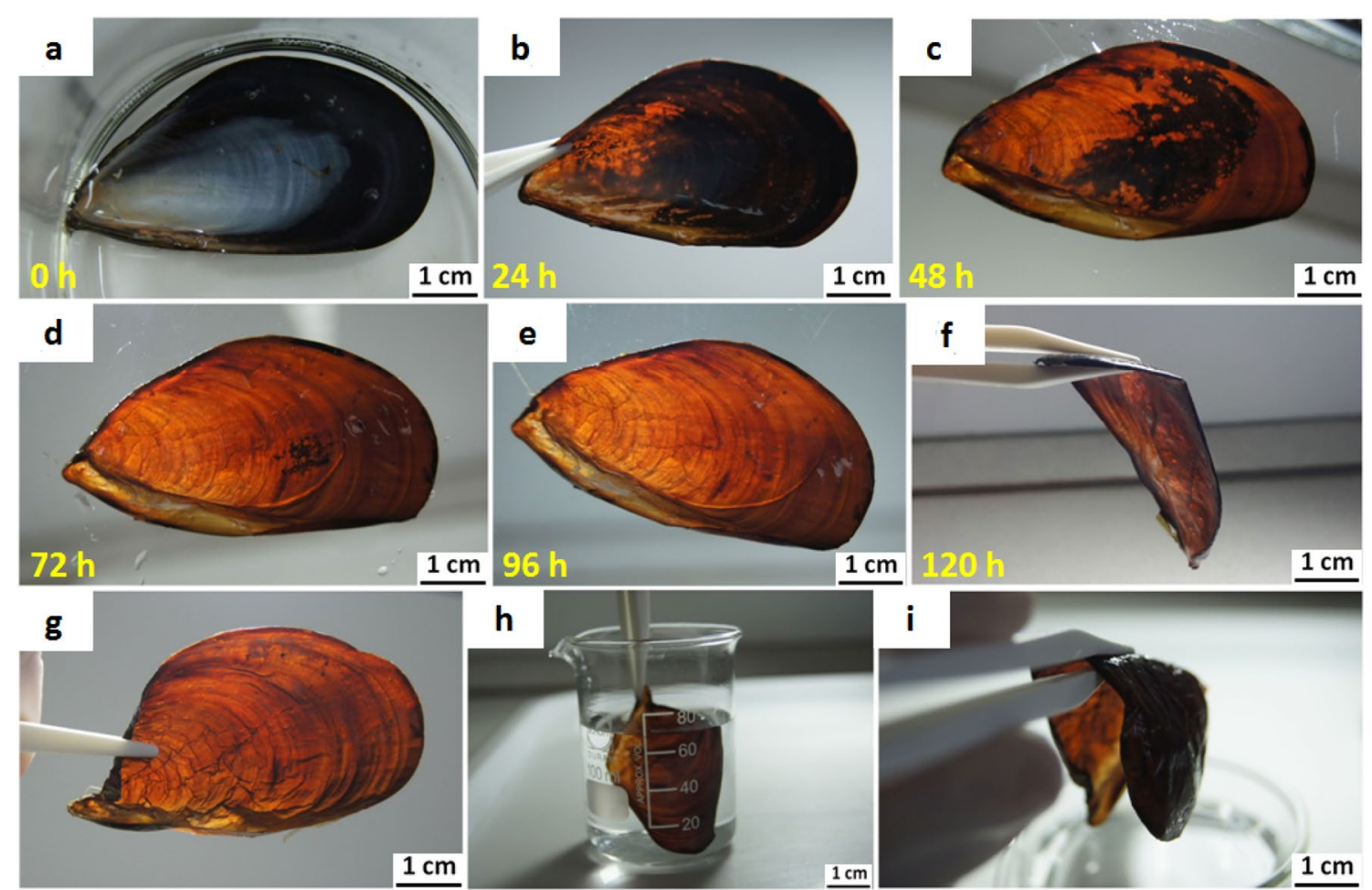

Fig. 7 Visualization of conchix isolation from the shell of $M$. galloprovincialis (a) using EDTA solution $(174 \mathrm{~g} / \mathrm{L} ; \mathrm{pH} 7.25)$ at $39{ }^{\circ} \mathrm{C}$. Isolated organic phase resembles the size and shape of the original shell $(\mathbf{b}-\mathbf{e})$. The confirmation of flexibility after $120 \mathrm{~h}$ (f). Also initially dried for storage conchixes (g) shows similar features (i) after 10 min. insertion into dist. $\mathrm{H}_{2} \mathrm{O}$ at room temperature source of immense amounts of shell waste (Fig. 8) in the locations of their habitat.

As reviewed by Cusack and co-workers [105], Haliotis species are recognized as a well-investigated model mollusk with respect to the understanding of their shell ultrastructure and organization [106], mechanisms of biomineralization [107] as well as their proteomics [108]. Traditionally, the most focus of investigators has been attracted to nacreous layers of the abalones shells. Using partial demineralization of red abalone (H. rufescens) shell nacre with 0.6 MEDTA at a pH of 8.0, Meyers and co- workers [109] isolated organic interlamellar up to $20 \mu \mathrm{m}$ thick mesolayers and showed how these mesolayers retain stiffness of the nacre. In contrast to this report, we have isolated the complete organic scaffold from the abalone shell (Fig. 8). The interface between mineral and organic phases that retain stiffness of the whole shell can be well visualized using digital microscopy (Fig. 8c, d). As in the case of L. elliptica (Figs. 4, 5), the conchix of $H$. tuberculata understudy seems to be firmly ingrown into the mineral phase and does not fall off independently. We suggest that isolated conchix contains all organic compounds (i.e. chitin, specific acidic and other shell matrix proteins) previously reported in the nacreous layer [110] as well as those located in periostracum, the outermost organic layer that covers the abalone shell. The greenish color of the isolated conchix suggests localization of some pigments, whose nature and origin should be investigated in the future.

Next, we chose the freshwater bivalve Corbicula $f l u$ minea (Müller, 1774) (Fig. 9a), which is an invasive species in Germany present since 1985 [111]. Similarly, with the demineralization results of the aforementioned mollusks, we obtained a conchix containing brownish colored pigments (Fig. 9b, c). Due to the recognition that shells of bivalves mostly contains quinone-tanned proteins within their periostracum [112-116], we can suggest their presence is in the conchix of this mollusk as well. It has been hypothesized that the tanning probably provides a rapid turnover from soluble to insoluble protein phases within the multilayer-structured uncalcified periostracum [117]. The function of this complex organic structure "is to provide waterproof support and a substrate for the growth of the outer shell layer. Examination of the inner surface of the periostracum shows crystal seeds upon it. The periostracum also has a protective function in forming a waterproof covering to the shell and preventing the corrosion of the calcified shell by acidic waters" [117].

SDS-PAGE analysis of the water insoluble conchix of $C$. fluminea (Fig. 9d) allows us to isolate proteins. After staining with Coomassie blue dye the presence of clear bands corresponding to certain peptides with molecular weight definitively lower than that of collagen (i.e. $250 \mathrm{kDa}$ ). 


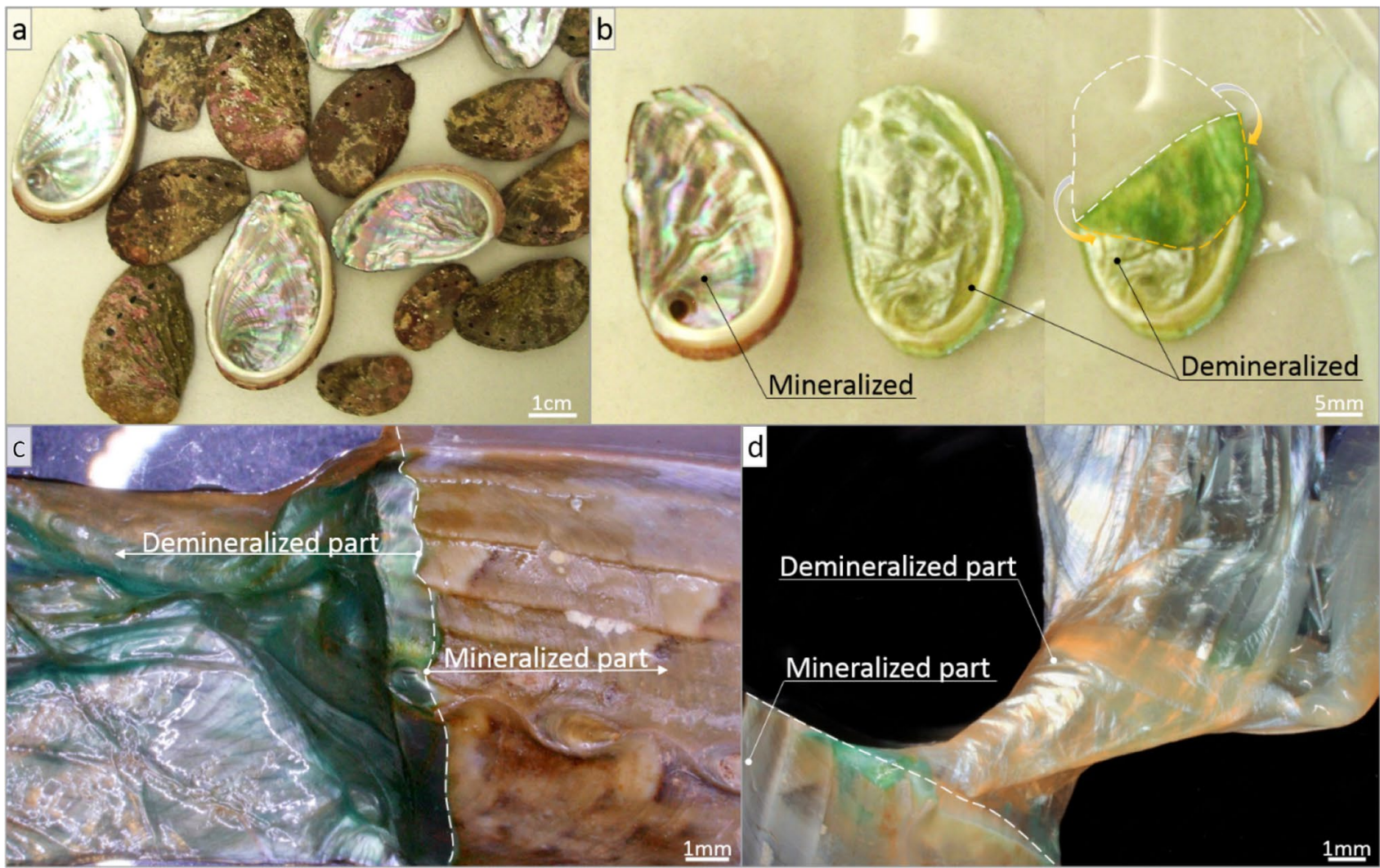

Fig. 8 Shells of $H$. tuberculata (a) constitute a massive waste of the marine processing industry. They can be effectively demineralized with Osteosoft solution at $37^{\circ} \mathrm{C}$ during 3-5 days with the aim to obtain mineral-free, soft organic scaffolds (b). Organic matrix remains so firmly rooted in the partially demineralized $H$. tuberculata shell (c) that it does not fall off even when trying to unscrew it (d)
Obtaining of well-presented bands assumes their presence in an amount that will be enough for successful identification of corresponding peptides by further proteomic analysis.

To obtain an understanding of the ultrastructural organization of this conchix, we carried out also TEM investigations, which confirm the presence of regularly striated nanofibrils (Fig. 10). Their structure seems to be similar to that reported previously for structural protein observed using TEM in the periostracum of gastropod Buccinum undatum L. [118].

The principle of gentle demineralization using EDTAbased solutions was also effective for the shells of terrestrial gastropods under study (Fig. 11). We believe that all conchixes represented in this study contain biomacromolecules which belonging to the organic phase of molluscan shell that is not water soluble. Consequently, it is logical to suggest the occurrence of periostracum (with related to its proteins), chitin and conchiolin. The term conchiolin refers to the insoluble residue remaining after shell decalcification [119]. Conchiolin sheets have been described in extant [120] as well as fossil [121] molluscan shells. It was experimentally shown that in the shell of M. edulis "the same conchiolin structure is associated with aragonite in mother-of-pearl and with calcite in the prismatic layer" [122]. However, in the case of shell disease similar to Brown Ring Disease of clams in abalone $H$. tuberculate large conchiolin deposit has been detected on the inner surface of the shell [123].

\section{Conclusions}

Conchixes isolated by us from gently demineralized molluscan shells are a biocomposite material containing a complete set of biomacromolecules, with the exception of watersoluble ones, that were originally present in shells. The next step in the study and practical application of these biological scaffolds with complex biomacromolecular content is associated with both detailed bioanalytical and toxicological work on their characterizations well as the determination and development of cost-effective areas for their use. In accordance with our ideas, these matrices can find applications in pharmacy and cosmetics in the form of corresponding drugs, biologically active pigments (i.e. carothenoids, polyphenols), extracts and hydrolysates for skin repair (Fig. 12).

In the case of development of large-scale demineralization processing and its optimization with respect of bulk 
Fig. 9 Shells of freshwater bivalve $C$. fluminea (Müller, 1774) (a) can be simply demineralized using EDTA solution at $37{ }^{\circ} \mathrm{C}$ during $3-5$ days (b). Isolated organic scaffolds (c) remains to be pigmented after this kind of gentle demineralization. SDS-PAGE analysis (d) allows us to detect the presence of clear bands corresponding to certain peptides, which should be identified using proteomic analysis

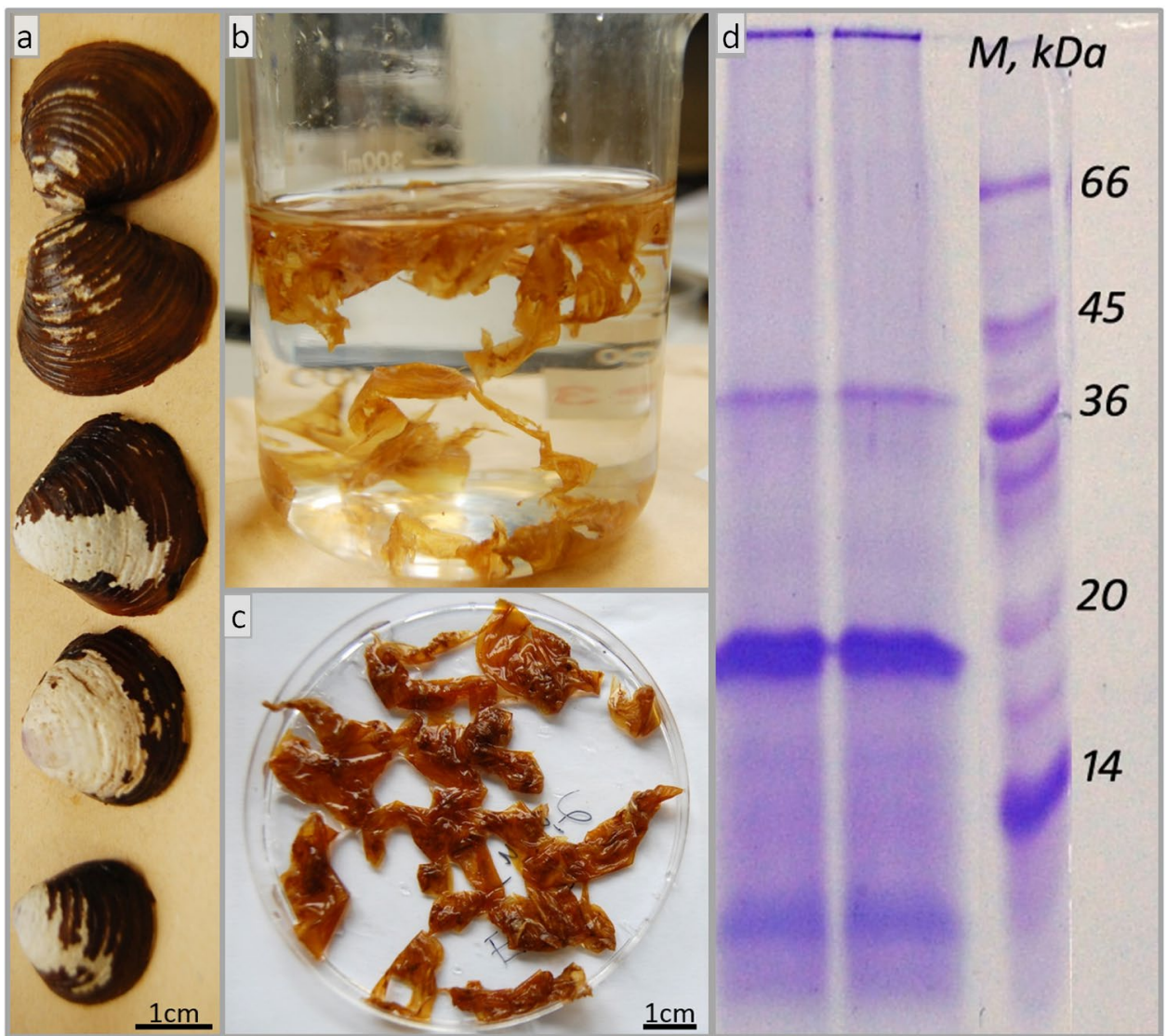

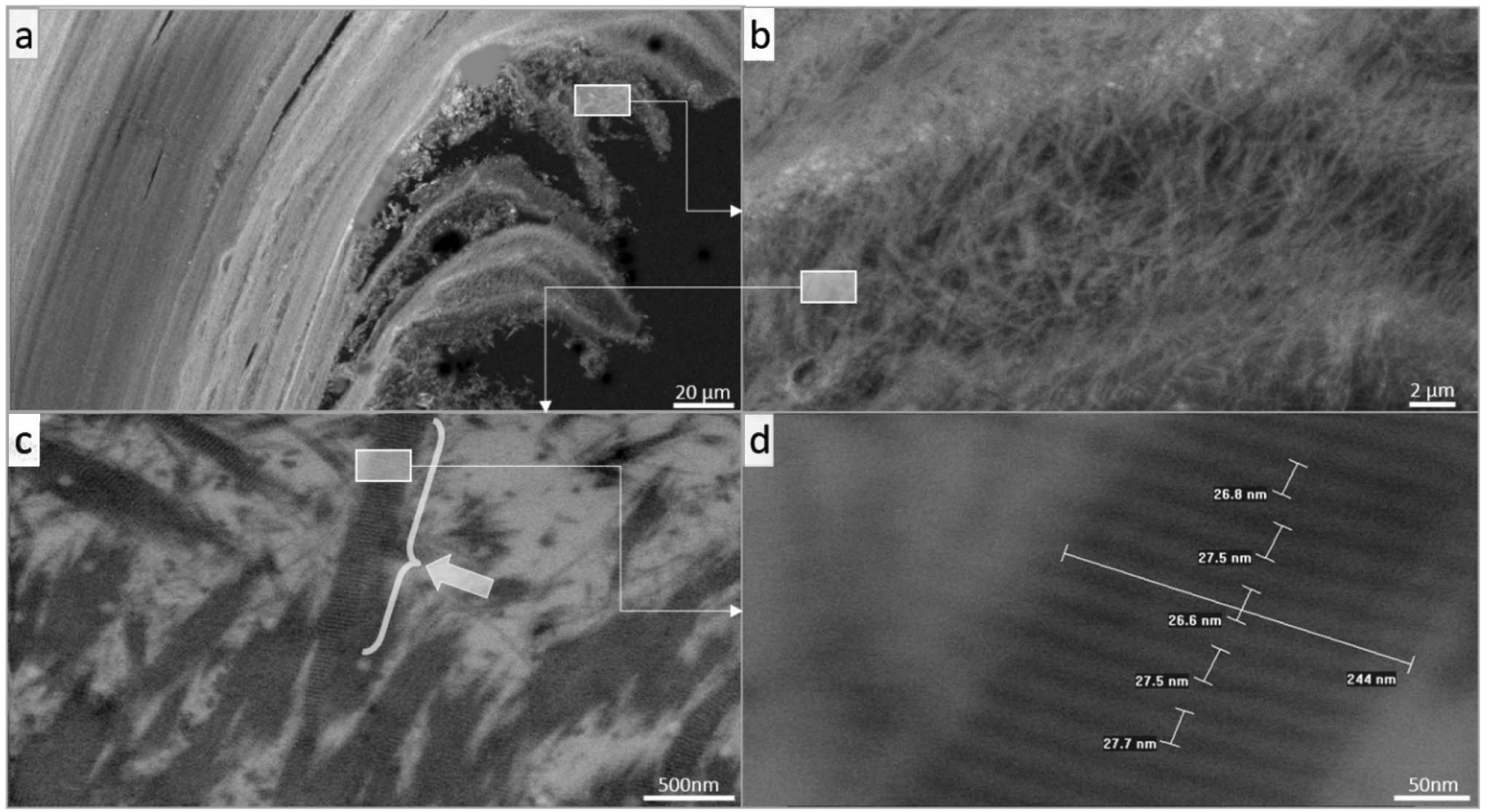

Fig. 10 SEM imagery (a) of selected region of $C$. fluminea organic matrix (see Fig. 9c) allows visualizing its nano-fibrous architecture (b). TEM images at higher magnification, show characteristic striation (c) of individual fibres becomes detectable. Nanostructural organization of such striated fibres (d) remains to be similar to that reported previously for periostracum in other mollusks species [118] 


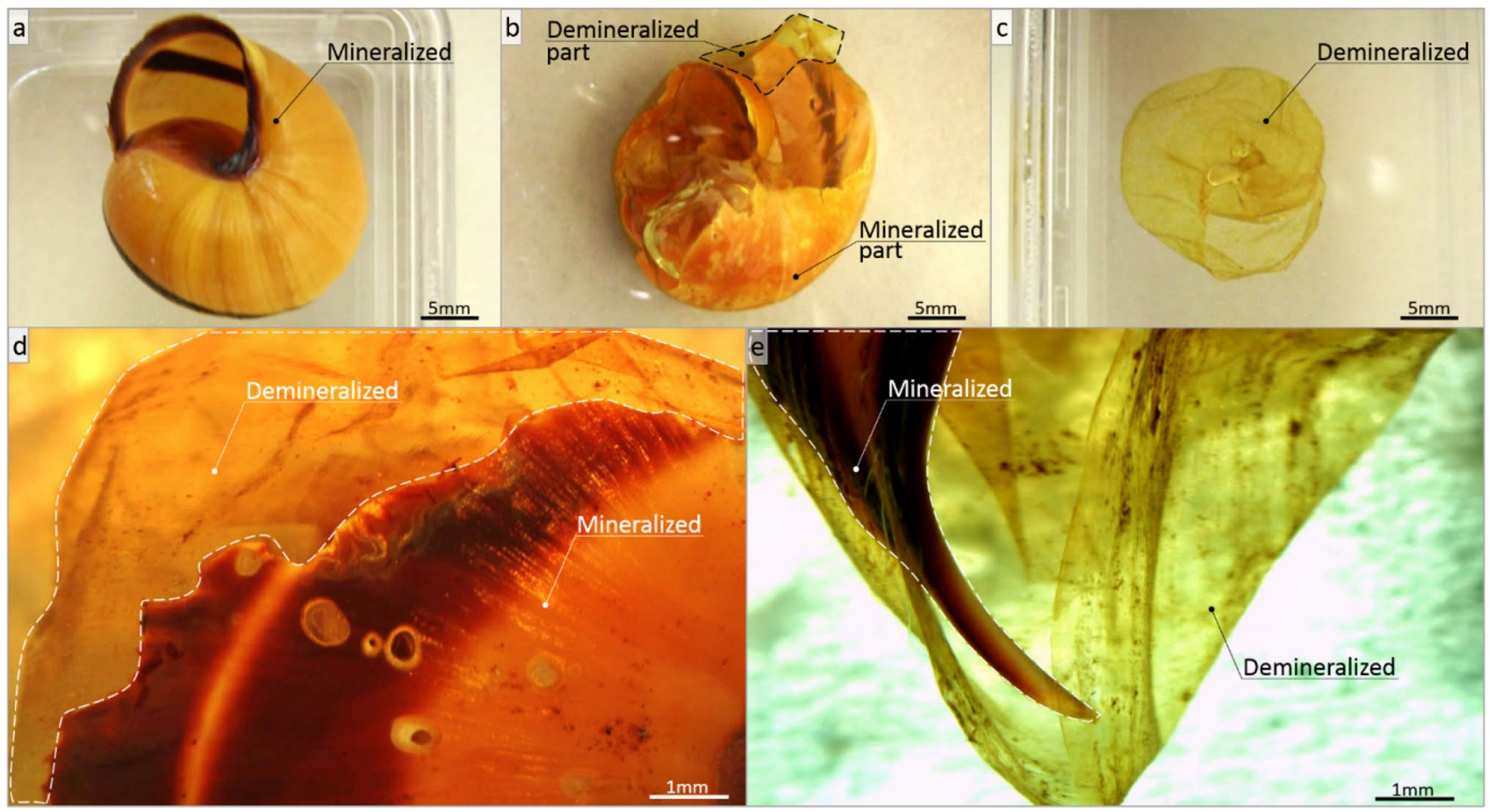

Fig. 11 Organic scaffolds (c) can be simply isolated step-by step (b) using Osteosoft $®$ solution also from shells of terrestrial molluscs such as $C$. nemoralis (Gastropoda) (a). Light microscopy allows observing regulated partial demineralization of the snail shells $(\mathbf{d}, \mathbf{e})$

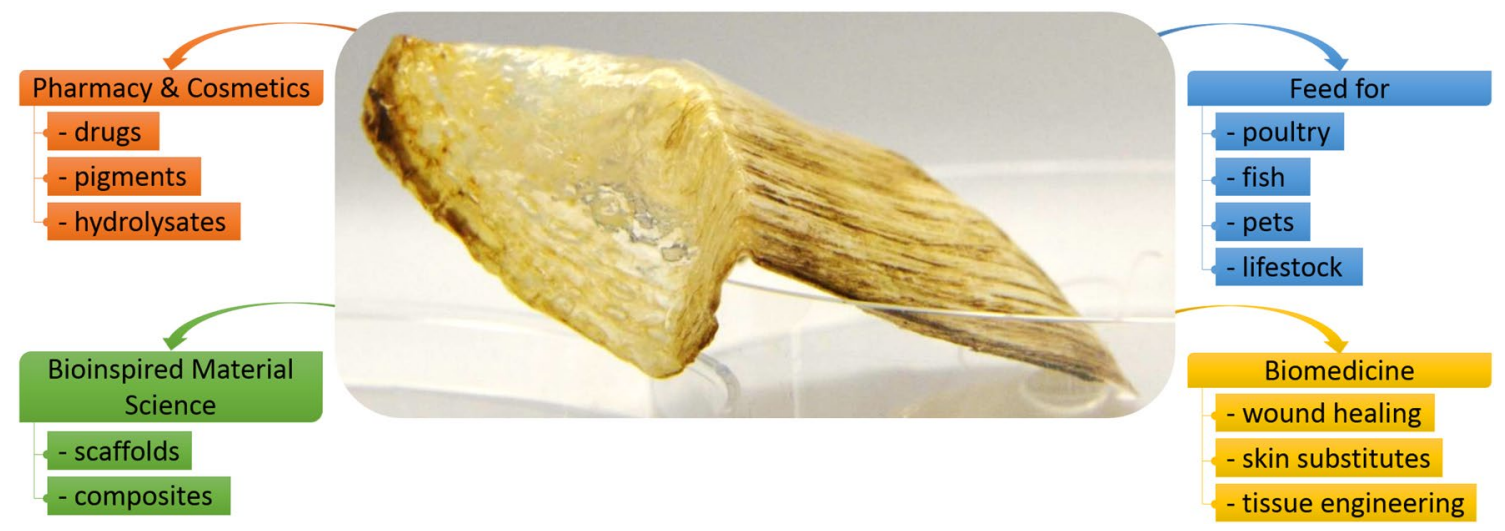

Fig. 12 Overview of the proposed strategies with respect to possible practical applications of molluscan conchixes in diverse fields

production of molluscan conchixes, they could be used as feed supplements for poultry, fish, livestock and pets. No less intriguing is the question of the possible use of this biomaterial in food by humans. The possible application of these biological constructs in biomedicine (i.e. skin substitutes, wound healing, and scaffolds for tissue engineering) and bioinspired materials science together with biomimetics cannot be ruled out. We are also committed to the need to study these matrices as sources of additional information on controlling changes in the environment under the influence of a wide variety of anthropogenic and climatic factors.
Acknowledgements Open Access funding provided by Projekt DEAL. We thanks Dr. Harald Poigner and Prof. Alexander Ereskovsky for specimens of L. elliptica and H. tuberculate shells, respectively.

Funding This work was partially supported by DFG Project HE 394/3, SMWK Project no. 02010311 (Germany), by the Ministry of Science of Montenegro in the frame of ShellMED project (01-789/2) and by the Ministry of Science and Higher Education (Poland) through a financial subsidy to PUT, No. 0912/SBAD/2006 (MW). Marcin Wysokowski is financially supported by the Polish National Agency for Academic Exchange (PPN/BEK/2018/1/00071). 


\section{Compliance with ethical standards}

Conflict of interest The authors declare that there is no conflict of interests regarding the publication of this manuscript. Prof. Werner Müller (Germany)

Consent to participate All of the co-workers have agreed to participate.

Consent for publication All of the co-workers have agreed to publication.

Open Access This article is licensed under a Creative Commons Attribution 4.0 International License, which permits use, sharing, adaptation, distribution and reproduction in any medium or format, as long as you give appropriate credit to the original author(s) and the source, provide a link to the Creative Commons licence, and indicate if changes were made. The images or other third party material in this article are included in the article's Creative Commons licence, unless indicated otherwise in a credit line to the material. If material is not included in the article's Creative Commons licence and your intended use is not permitted by statutory regulation or exceeds the permitted use, you will need to obtain permission directly from the copyright holder. To view a copy of this licence, visit http://creativecommons.org/licenses/by/4.0/.

\section{References}

1. O.B. Boggild, in Ammonoid Paleobiology, ed. by N.H. Landman, K. Tanabe, R.A. Davis, Selsk. Skr. Vidensk, vol. 2 (1930), pp. 231-326. https://link.springer.com/book/10.1007\%2F978 -1-4757-9153-2\#about

2. F. Marin, G. Luquet, B. Marie, D. Medakovic, Curr. Top. Dev. Biol. 80, 209-276 (2008)

3. F. Marin, N. Le Roy, B. Marie, Front Biosci. (Sch. Ed.) 4, 1099 (2012)

4. T. Furuhashi, C. Schwarzinger, I. Miksik, M. Smrz, A. Beran, Comp. Biochem. Physiol. B Biochem. Mol. Biol. 154(3), 351371 (2009)

5. M. Suzuki, H. Nagasawa, Can. J. Zool. 91(6), 349 (2013)

6. K.M. Kocot, F. Aguilera, C. McDougall, D.J. Jackson, B.M. Degnan, Front Zool. 13(23) (2016)

7. L. Pfister, C. Grave, J. Beisel, J.J. McDonnell, Sci. Rep. 9, 4312 (2019)

8. C.R. Kanmani, V. Thiyagarajan, Mar. Environ. Res. 155, 104883 (2020)

9. M. Zuykov, E. Pelletier, D.A. Harper, Chemosphere 93(2), 201 (2013)

10. S. Bruggmann, R.M. Klaebe, C. Paulukat, R. Frei, Geobiology 17(4), 417 (2019)

11. J.D. Currey, Symp. Soc. Exp. Biol. 34, 75 (1980)

12. S. Kamat, X. Su, R. Ballarini, A.H. Heuer, Nature 405, 1036 (2000)

13. W. Yang, N. Kashani, X.W. Li, G.P. Zhang, M.A. Meyers, Mater. Sci. Eng. C 31, 724 (2011)

14. I. Hrabánková, J. Frýda, J. Šepitka, T. Sasaki, B. Frýdová, J. Lukeš, Comput. Methods Biomech. 16(1), 287 (2013)

15. X.W. Li, H.M. Ji, W. Yang, G.P. Zhang, D.L. Chen, J. Mech. Behav. Biomed. Mater. 74, 54 (2017)

16. H. Ji, X. Li, D. Chen, Sci. Rep. 7, 40043 (2017)

17. A.G. Checa, F.J. Esteban-Delgado, A.B. Rodríguez-Navarro, J. Struct. Biol. 157, 393 (2007)
18. M.A. Meyers, P.Y. Chen, A.Y.M. Lin, Y. Seki, Prog. Mater Sci. 53(1), 1 (2008)

19. S.M. de Paula, M. Silveira, Micron 40(7), 669 (2009)

20. M. Connors, H. Ehrlich, M. Hog, C. Godeffroy, S. Araya, I. Kallai, D. Gazit, M.C. Boyce, C. Ortiz, J. Struct. Biol. 177, 314 (2012)

21. J.P. Morris, Y. Wanga, T. Backeljauab, G. Chapelle, Mar. Genom. 27, 85 (2016)

22. R. Yadav, R. Goud, A. Dutta, X. Wang, M. Naebe, B. Kandasubramanian, Ind. Eng. Chem. Res. 57(32), 10832 (2018)

23. V. Schoeppler, R. Lemanis, E. Reich, T. Pusztai, L. Gránásy, I. Zlotnikov, Proc. Natl. Acad. Sci. 116(41), 20388 (2019)

24. M. Strąg, Ł. Maj, M. Bieda, P. Petrzak, A. Jarzębska, J. Gluch, E. Topal, K. Kutukova, A. Clausner, W. Heyn, K. Berent, K. Nalepka, E. Zschech, A.G. Checa, K. Sztwiertnia, J. Nanomater. 10, 634 (2020)

25. M.C. Barros, P.M. Bello, M. Bao, J.J. Torrado, J. Clean. Prod. 17, 400 (2009)

26. R.A. de Alvarenga, B.M. Galindro, C.F. Helpa, S.R. Soares, J. Environ. Manag. 106, 102 (2012)

27. J.P. Morris, T. Backeljau, G. Chapelle, Rev. Aquacult. 11, 42 (2019)

28. M. Wysokowski, T. Machalowski, I. Petrenko, C. Schimpf, D. Rafaja, R. Galli, J. Ziętek, S. Pantović, A. Voronkina, V. Kovalchuk, V.N. Ivanenko, B.W. Hoeksma, C. Diaz, Y. Khrunyk, A.L. Stelling, M. Giovine, T. Jesionowski, H. Ehrlich, Mar. Drugs 18, 123 (2020)

29. G. Avagnina, Snail Breeding-Intensive Snail Breeding Complete Production Cycle Trading (The International Snail Breeding Institute Cherasco, Cherasco, 2006)

30. A. Toader-Williams, B. Otilia, Bul. Univ. Agric. Sci. Vet. Med. Cluj-Napoca Anim. Sci. Biotechnol. 68, 287-295 (2011)

31. J.M. Paris, J.G. Roessler, C.C. Ferraro, H.D. DeFord, T.G. Townsend, J. Clean. Prod. 121, 1 (2016)

32. A. Edalat-Behbahani, F. Soltanzadeh, M. Emam-Jomeh, Z. Soltan-Zadeh, Eur. J. Environ. Civ. Eng. (2019). https://doi. org/10.1080/19648189.2019.1607780

33. H.T. Silva, J. Mesquita-Guimarães, B. Henriques, F.S. Silva, M.C. Fredel, Resources 8, 13 (2019)

34. A. Domingues, I.C. Rosa, J.P. da Costa, T.A.P. Rocha-Santos, F.J.M. Gonçalves, R. Pereira, J.L. Pereira, J. Clean. Prod. 252, $119773(2020)$

35. G.L. Yoon, B.T. Kim, B.O. Kim, S.H. Han, Waste Manag. 23, 825 (2003)

36. Y. Hou, Y.A. Shavandi, A. Carne, A.A. Bekhit, T.B. Ng, R.C.F. Cheung, A.E.A. Bekhit, Crit. Rev. Environ. Sci. Technol. 46, 1047 (2016)

37. M.I. Jones, L.Y. Wang, A. Abeynaike, D.A. Patterson, Adv. Appl. Ceram. 110, 280 (2011)

38. J. Chen, Z. Wen, S. Zhong, Z. Wang, J. Wu, Q. Zhang, Mater. Des. 87, 445 (2015)

39. H. Li, D. Jin, R. Li, X. Li, JOM 67(4), 720 (2015)

40. M.Z.A. Khiri, K.A. Matori, N. Zainuddin, C.A.C. Abdullah, C.N. Alassan, N.F. Baharuddin, M.H.M. Zaid, Springerplus 5(1206), (2016)

41. S.C. Wu, H.C. Hsu, S.K. Hsu, C.P. Tseng, W.F. Ho, Adv. Powder Technol. 28, 1154 (2017)

42. J.N. Murphy, C.M. Schneider, L.K. Mailänder, Q. Lepillet, K. Hawboldt, F.M. Kerton, Green Chem. 21, 3920 (2019)

43. A. Perea, T. Kelly, Y. Hangun-Balkir, Green Chem. Lett. Rev. 9(1), 27 (2016)

44. M. Jovic, M. Mandic, M. Sljivic-Ivanovic, I. Smiciklas, Stud. Mar. 32(1), 47 (2019)

45. I.M. Weiss, V. Schönitzer, J. Struct. Biol. 153, 264 (2006)

46. M. Suzuki, S. Sakuda, H. Nagasawa, Biosci. Biotechnol. Biochem. 71, 1735 (2007) 
47. H. Ehrlich, Int. Geol. Rev. 52, 661 (2010)

48. J. Bezares, R.J. Asaro, V.A. Lubarda, J. Theor. Appl. Mech. Pol. 39(4), 343 (2012)

49. O.B.A. Agbaje, I. Ben Shir, D.B. Zax, A. Schmidt, D.E. Jacob, Acta Biomater. 80, 176 (2018)

50. I.M. Weiss, in Extracellular Sugar-Based Biopolymers Matrices, ed. by E. Cohen, H. Merzendorfer (Springer, Cham, 2019), pp. $57-93$

51. J.C. Marxen, M. Hammer, T. Gehrke, W. Becker, Biol. Bull. 194(2), 231 (1998)

52. O.B.A. Agbaje, D.E. Thomas, B.V. Mclnerney, M.P. Molloy, D.E. Jacob, Mar. Biol. 164, 208 (2017)

53. O.B.A. Agbaje, D.E. Thomas, J.G. Dominguez, B.V. Mclnerney, M.A. Kosnik, D.E. Jacobet, J. Mater. Sci. 54, 4952 (2019)

54. S. Sudo, T. Fujikawa, T. Nagakura, T. Ohkubo, K. Sakaguchi, M. Tanaka, K. Nakashima, T. Takahashi, Nature 387(6633), 563 (1997)

55. Y. Dauphin, J. Biol. Chem. 278(17), 15168 (2003)

56. F. Marin, G. Luquet, Mater. Sci. Eng. C 25(2), 105 (2005)

57. B.A. Gotliv, L. Addadi, S. Weiner, ChemBioChem 4(6), 522 (2003)

58. M. Suzuki, T. Okumura, H. Nagasawa, T. Kogure, J. Cryst. Growth. 337, 24 (2011)

59. F. Marin, B. Marie, S.B. Hamada, P. Ramos-Silva, N. LeRoy, N. Guichard, S.E. Wolf, C. Montagnani, C. Joubert, D. Piquemal, D. Daulner, Y. Gueguen, in Recent Advances in Pearl Research, ed. by S. Watabe, K. Maeyama, H. Nagasawa (TERRAPUB, Tokyo, 2013), pp. 149-166

60. T. Samata, M. Ogura, J. Foss. Res. 30, 66 (1997)

61. B. Farre, Y. Dauphin, Comp. Biochem. Physiol. B. 152, 103 (2009)

62. J. Andre, Rev. Suisse Zool. 3, 429 (1895)

63. A. Comfort, Nature 162, 851 (1948)

64. A. Comfort, Proc. Malacol. Soc. Lond. 28, 79 (1950)

65. L. Bergamonti, D. Bersani, S. Mantovan, P.P. Lottici, EJM 25, $845(2014)$

66. S. Affenzeller, K. Wolkenstein, H. Frauendorf, D.J. Jackson, Front. Zool. 16, 47 (2019)

67. N. Watabe, K.M. Wilbur, Nature 188, 334 (1960)

68. M. Wysokowski, M. Zaton, V.V. Bazhenov, T. Behm, A. Ehrlich, A.L. Stelling, M. Hog, H. Ehrlich, Paleobiology 40(4), 529 (2014)

69. R. Araujo, G. Delvene, M. Munt, J. Molluscan Stud. 80, 74 (2014)

70. S. Weiner, H. Lowenstam, B. Taborek, L. Hood, Paleobiology 5(2), 144 (1979)

71. H. Ehrlich, P. Koutsoukos, K. Demadis, O. Pokrovsky, Micron 39, 1062 (2008)

72. H. Ehrlich, P. Koutsoukos, K. Demadis, O. Pokrovsky, Micron 40, 169 (2009)

73. H. Ehrlich, P. Etnoyer, S. Litvinov, M. Olennikova, H. Domaschke, T. Hanke, R. Born, H. Worch, Materialwiss. Werkst. 37(6), 552 (2006)

74. M. Bo, G. Bavestrello, D. Kurek, S. Paasch, E. Brunner, R. Born, R. Galli, A.L. Stelling, V.N. Sivkov, O.V. Petrova, D. Vyalikh, K. Kummer, S.L. Molodtsov, D. Nowak, J. Nowak, H. Ehrlich, Int. J. Biol. Macromol. 51, 129 (2012)

75. H. Ehrlich, Y.N. Elkin, A.A. Artyoukov, E. Kozlovskaya, V.A. Stonik, P.P. Safronov, D.V. Kurek, V.V. Bazhenov, K. Kummer, D. Vyalykh, S. Molodtsov, V. Sivkov, R. Born, M. Ruhnow, H. Meissner, G. Richter, J. Adv. Microsc. Res. 5, 100 (2010)

76. V. Marrocco, F. Zangaro, A. Sicuro, M. Pinna, Nat. Conserv. 33, 21 (2019)

77. H.J. Choi, I.Y. Ahn, K.W. Kim, H.A. Kim, I.S. Lee, B. Environ, Contam. Toxicol. 71(1), 83 (2003)
78. H. Poigner, D. Wilhelms-Dick, D. Abele, M. Staubwasser, S. Henkel, Chemosphere 134, 294 (2015)

79. C. Vodopivez, A. Curtosi, E. Villaamil, P. Smichowski, E. Pelletier, W.P. Mac Cormack, Sci. Total Environ. 502, 375 (2015)

80. A.L. Webb, K.A. Hughes, M.M. Grand, M.C. Lohan, L.S. Peck, Sci. Total Environ. 698, 134268 (2020)

81. V. Cummings, J. Hewitt, A. Van Rooyen, K. Currie, S. Beard, S. Thrush, J. Norkko, N. Barr, P. Heath, N.J. Halliday, R. Sedcole, A. Gomez, C. McGraw, V. Metcalf, PLoS ONE 6(1), e16069 (2011)

82. C.H. Bylenga, V.J. Cummings, K.G. Ryan, PLoS ONE 12(4), e0175706 (2017)

83. D. Dick, E. Philipp, M. Kriews, D. Abele, Aquat. Toxicol. 84(4), 450 (2007)

84. E.M. Harper, M.S. Clark, J.I. Hoffman, E.E. Philipp, L.S. Peck, S.A. Morley, PLoS ONE 7(9), e46341 (2012)

85. S.A. Morley, T. Hirse, M.A. Thorne, H.O. Pörtner, L.S. Peck, Comp. Biochem. Phys. A 162(1), 16 (2012)

86. G. Husmann, E.E. Philipp, D. Abele, Mar. Environ. Res. 118, 57 (2016)

87. R. Hoffmann, F. Pasotti, S. Vázquez, N. Lefaible, A. Torstensson, W. MacCormack, F. Wenzhöfer, U. Braeckman, PLoS ONE 13(12), e0207917 (2018)

88. V.A. Sleight, B. Marie, D.J. Jackson, E.A. Dyrynda, A. Marie, M.S. Clark, Sci. Rep. 6, 36978 (2016)

89. I. Kobayashi, T. Samata, Mater. Sci. Eng. C 26, 692 (2006)

90. S. Weiner, L. Hood, Science 190, 987 (1975)

91. S. Weiner, W. Traub, FEBS Lett. 111, 311 (1980)

92. R. Martinović, S. Kolarević, M. Kračun-Kolarević, J. Kostić, S. Marković, Z. Gačić, Z. Kljajić, B. Vuković-Gačić, Mar. Environ. Res. 108, 83 (2015)

93. R. Martinović, S. Kolarević, M. Kračun-Kolarević, J. Kostić, S. Jokanović, Z. Gačić, D. Joksimović, M. Đurović, Z. Kljajić, B. Vuković-Gačić, Environ. Toxicol. Pharmacol. 47, 165 (2016)

94. S. Ancora, F. Rossi, M. Borgese, C. Pirrone, I. Caliani, S. Cappello, G. Mancini, N. Bianchi, C. Leonzio, G. Bernardini, R. Gornati, Mar. Biotechnol. 22, 411 (2020)

95. D. Joksimović, A. Castelli, A. Perošević, D. Djurović, S. Stanković, J. Trace Elem. Med. Biol. 50, 601 (2018)

96. A. Perošević, D. Joksimović, D. Đurović, I. Milašević, M. Radomirović, S. Stanković, J. Trace Elem. Med. Biol. 50, 554 (2018)

97. H. Baltas, E. Kiris, G. Dalgic, U. Cevik, Mar. Pollut. Bull. 107(1), 402 (2016)

98. V.U. Ceccherelli, A. Barboni, Aquaculture 34(1-2), 101 (1983)

99. J.A. Theodorou, J. Viaene, P. Sorgeloos, I. Tzovenis, J. Shellfish Res. 30(3), 859 (2011)

100. K. Michalek, A. Ventura, T. Sanders, Mar. Genomics 27, 3 (2016)

101. F.M. Suplicy, Rev. Aquacult. 12, 204 (2020)

102. B.J. Becker, F.J. Fodrie, P.A. McMillan, L.A. Levin, Limnol. Oceanogr. 50(1), 48 (2005)

103. A.C. Smaal, L. Duren, in Goods and Services of Marine Bivalves, ed. by A.C. Smaal, J.G. Fereira, J. Grant, J.K. Petersen, Ø. Strand (Springer, Cham, 2019), pp. 451-483

104. J.W.M. Wijsman, K. Troost, J. Fang, A. Roncarati, in Goods and Services of Marine Bivalves, ed. by A.C. Smaal, J.G. Fereira, J. Grant, J.K. Petersen, Ø. Strand (Springer, Cham, 2019), pp. 7-27

105. M. Cusack, D. Guo, P. Chung, N.A. Kamenos, J. Struct. Biol. $\mathbf{1 8 3}(2), 165(2013)$

106. S. Auzoux-Bordenave, A. Badou, B. Gaume, S. Berland, M.N. Helléouet, C. Milet, S. Huchette, J. Struct. Biol. 171, 277 (2010)

107. G. Falini, G. Sartor, D. Fabbri, P. Vergni, S. Fermani, A.M. Belcher, G.D. Stucky, D.E. Morse, J. Struct. Biol. 173, 128 (2011) 
108. B. Marie, A. Marie, D.J. Jackson, L. Dubost, B.M. Degnan, C. Milet, F. Marin, Proteome Sci. 8, 54 (2010)

109. M.I. Lopez, P.E. Martinez, M.A. Meyers, Acta Biomater. 10, 2056 (2014)

110. M. Raj, S.P. Patil, B. Markert, J. Compos. Sci. 4, 35 (2020)

111. K. Grabow, A. Martens, Mitt. Dtsch. Malak. Ges. 56-57, 19 (1995)

112. C.H. Brown, J. Cell Sci. 93, 487 (1952)

113. R.E. Hillman, Science 134(3492), 1754 (1961)

114. D.F. Travis, J. Ultrastruct. Res. 23, 183 (1968)

115. V.R. Meenakshi, P.E. Hare, N. Watabe, K.M. Wilbur, Corap. Biochera. Physiol. 29, 611 (1969)

116. A. Checa, Tissue Cell 32, 405 (2000)

117. J.D. Taylor, W.J. Kennedy, Calcif. Tissue Res. 3, 274 (1969)

118. S. Hunt, K. Oates, Experientia 26, 1196 (1970)
119. M.A. Crenshaw, in Skeletal Biomineralization: Patterns, Processes and Evolutionary Trends, ed. by J.G. Carter (Van Nostrand Reinhold, New York, 1990), pp. 1-9

120. E.M. Harper, Palaeontology 37, 551 (1994)

121. S. Bricteux-Grégoire, M. Florkin, C. Grégoire, Comp. Biochem. Physiol. 24, 567 (1968)

122. C. Gregoire, J. Biophys. Biochem. Cytol. 9(2), 395 (1961)

123. S. Huchette, C. Paillard, J. Clavier, R. Day, Dis. Aquat. Organ. 68(3), 267 (2006)

Publisher's Note Springer Nature remains neutral with regard to jurisdictional claims in published maps and institutional affiliations. 